Portland State University

PDXScholar

2014

\title{
DETERMINED: Start to Finish - Year 1 : the Freshman to Sophomore Experience
}

Kathleen Steppe

Portland State University

Follow this and additional works at: https://pdxscholar.library.pdx.edu/honorstheses

Let us know how access to this document benefits you.

\section{Recommended Citation}

Steppe, Kathleen, "DETERMINED: Start to Finish - Year 1 : the Freshman to Sophomore Experience" (2014). University Honors Theses. Paper 44.

https://doi.org/10.15760/honors.71

This Thesis is brought to you for free and open access. It has been accepted for inclusion in University Honors Theses by an authorized administrator of PDXScholar. Please contact us if we can make this document more accessible: pdxscholar@pdx.edu. 


\title{
DETERMINED: Start to Finish
}

Year 1: The Freshman to Sophomore Experience

\author{
by \\ Kathleen Steppe \\ An undergraduate honors thesis submitted in partial fulfillment of the \\ requirements for the degree of \\ Bachelor of Science \\ in \\ University Honors \\ and \\ Psychology
}

Thesis Advisers

Leslie B. Hammer, Ph.D. - Lead Adviser

Rachel Webb -M.S. Statistics

Scott Broussard - M.S.

Portland State University 


\begin{abstract}
For students, the first year of college holds with it specific challenges. This honors thesis describes elements of and provides valuable insight into the college student's journey, relative to their first-year experience. The largest portion of this thesis focused on review of literature pertaining to institutional support and college retention. This denotes the relationship between each consumer of higher education and the multitude of options from which they can choose to invest in to begin pursuit of their degree. Because of the varied relational aspects between institutional support and retention, also reviewed was literature aligned with efficacy of systems and efficacy of self. Upon review of the literature, perspectives melded into an effective contention to address the research question: How does institutional support lead to first-year college student retention? Conclusions have stipulated that institutional support is redefined based on diverse student populations in an effort to more formally nurture student engagement, college success, and enhance retention rates. These conclusions aligned with procurement of useful information and measureable outcomes, inferences thereof are duly noted in the latter part of this text. The journey through the literature review and the processes affiliated with producing this thesis proved life-altering. The results and conclusions thereof are an honor to share with each who reads this text.
\end{abstract}




\section{DETERMINED: Start to Finish}

\section{Year 1: The Freshman to Sophomore Experience}

Discourse related to the various layers and levels of defining, measuring, and increasing student retention is plentiful. The student must navigate elements of finding resources on their campus, financial aid, advising, housing, etc., beginning with the college application process. However, with so many elements of the educational structure which were created to formulate and mandate actions, one might postulate those who are managing institutions are responsible for each element of the structure. In that, those who are managing institutions administratively-from the national level of law makers to the local levels of college administrators-should openly and justly take responsibility for the state of the nation and the crises, such as exorbitant college student loan debt, facing consumers of higher education and the challenges they encounter. Clearly, navigating this multitude of responsibilities is a tremendous journey for any singular entity or conglomeration, even under the most charmed conditions. Yet and still, it requires a collectively stern focus and action should be immediately forthcoming. Exemplified in the 2014 Gallup-Purdue Index Report ${ }^{1}$,

The data presented in this report suggest...thinking about things that are more lasting than selectivity of an institution or any traditional measures of college. Instead, the answers may lie in what students are doing in college and how they are experiencing it. Those elements -more than any others - have a profound relationship to a person's life and career. Yet they are being achieved by too few. It should be a national imperative-

\footnotetext{
${ }^{1}$ See page $6<$ http://www.gallup.com/poll/168848/life-college-matters-life-college.aspx $>$; Link to request full report $\rightarrow$ < http://products.gallup.com/168857/gallup-purdue-index-inaugural-national-report.aspx >
} 
owned by higher education institutions, students, parents, businesses, non-profits, and government alike to change this (Great Jobs, Great Life, p. 6).

For students to remain determined (start to finish) along that often unclear path to and through higher education requires all parties involved to remain engaged in the process. In an effort to define and address some meaningful elements of successful student retention, examples of scholarship (past and present) are reviewed below, after purposefully being selected for this honors thesis. First, however, it is important to define some key terms reviewed in this framework related to the investigation of college retention:

- Retention rate is the percentage of a school's first-time, first-year undergraduate students who continue at that school the next year. For example, a student who studies full-time in the fall semester and keeps on studying in the program in the next fall semester is counted in this rate. See < https://fafsa.gov/help/fotw91n.htm > Retrieved online 23 May 2013;

- Institutional support includes monetary support such as grants, tuition remission, loans, work study, scholarships, as well as any other service or support that the student receives through the institution.

- $\quad$ Perceived self-efficacy is defined as people's beliefs about their capabilities to produce designated levels of performance that exercise influence over events that affect their lives. Self-efficacy beliefs determine how people feel, think, motivate themselves and behave (Bandura, 1994, p. 71).

Steadfastly revealed within this discourse is context related to the above descriptors, which demonstrated the direct need for further research and forward movement respective of supporting 
hypotheses aligned with alternately defining, redefining and providing institutional support. In an effort to contextualize key terms with regard to this subject matter, the author shares a point of clarity: the term-retention is aligned with institutions; subsequently, the term - persistence is aligned with students. In other words, institutions retain, students persist. Deeper dialogue of potential next steps with regard to redefining institutional support are considered. Doing so stands to benefit the institutions of higher-learning, while also likely to benefit a greater portion of consumers they serve. Parallel to the process, Vincent Tinto pointed out, "That high expectations and support go hand in hand with student success is not a new notion" (2012, p. 12). Collaboration and perspectives thereof as how best to address the mutual desire for increase in retention rates, accompanied by increase in the college success maintained by the first-year student provide a substantial basis for discussion.

Budgets are stretched and yes, times are tough. However, by focusing on the positive, systems can be aligned with forward movement and increased rates of retention. Confirmation of which is asserted by Tinto, 1987, "It is achievable within the confines of the existing institutional resources to increase retention...but such commitment does often require institutional change" (p. 187). Subsequent considerations, commitment, and support, which if effectively offered and monitored, would likely do more than improve the retention rates for college institutions; but also cohesively inspire ongoing expanded definitions of institutional support, and afford positive impacts associated with each student's perceived self-efficacy long term. An online book review, discovered when searching the topic of retention rates produced an address, which heightened the scholarly depth of authors Tinto and John P. Bean referencing both as "“fathers' of student retention research," the author of the book review (of College Student Retention: Formula for Student Success) further explicated, “Bean's chapter hammers home the necessity that retention 
is ultimately about institutional change, and unless colleges adhere to that belief, positive development in student retention are unlikely to happen” Student Success, January 2006, <StudentRetention.org> Retrieved 13 December 2013. Much scholarship of the two aforementioned authors was sought after along this path of literary discovery. Likewise, their scholarship was largely influential in perspective-building with regard to context within this thesis and the development of next steps further shared within future research sections.

Thesis and Purpose Statement. How does institutional support lead to first-year college student retention? The intent at this pedagogical juncture was to formulate next steps, hypotheses, research questions, and methodological outlooks which will concretely pave the way for future survey instrument development and assessment, related to my conceptual model (See Figure 1.). Initially this conceptual model aligns the relationship of engaging institutional support with college retention. Subsequently, this honors thesis entailed exploration of literature pertaining to college retention, institutional support, and perceived self-efficacy. More specifically, this honors thesis was written with retention of the first-year college student in mind.

\section{Figure 1:}

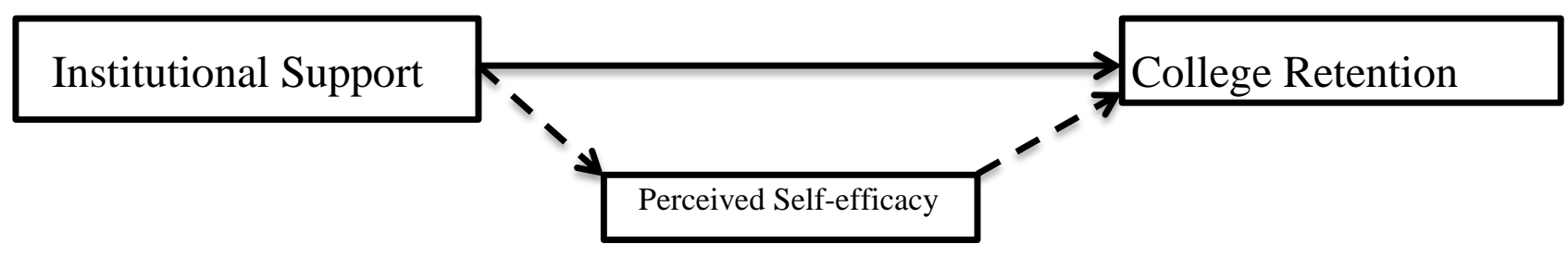

During the course of this project, portions of Portland State University Freshman Inquiry [FRINQ]-related data and discourse was assessed for educational purposes. Data collected during 2012-2013, pertaining to completed Prior-Learning Surveys and variables related to those 
retained the following fall term was of specific interest to the author. When assessing Portland State University (PSU) freshman, there does not appear to be a significant difference in rates of first-year retention and gender; however, a chi-square test could not be performed based on the small samples size relative to unidentified participant responses. However, there is a significant difference in first-year retention and ethnicity, $\chi^{2}(6, \mathrm{~N}=942)=13.28, \mathrm{p}=0.04$. Additionally, there is a significant difference in the first-year retention rates of those students with resident status versus those students with non-resident status, $\chi^{2}(1, N=942)=6.13, p=0.01$. The structure of the author's focus was on the full-time [12 or more credit hours per term], first-year student. Primary comparisons pertaining to the relationships between first-year retention and gender, first-year retention and ethnicity, first-year retention and residency status were assessed, as reflected by graphs and charts [See Appendix A and Appendix B]. Subsequently, any aforementioned and continued data assessments are duly intended for further use with respect to future projects. Moreover, the following honors thesis parallels this inaugural review of literature and summary thereof to an upcoming adult-learning series to be continued into the author's graduate program of study and beyond.

\section{Background}

In the $13^{\text {th }}$ century the world began describing systems and behaviors as efficacious, according to Webster's. ${ }^{2}$ Through review of the literature it was discovered, what is now referred to as "blaming the victim"- - was once viewed through the lends [sic] of psychology as a summary of reasons as to why a student quit college. In that, students who did not stay were thought to be less able, less motivated, and less willing to defer the benefits the institution was

${ }^{2}$ Efficacious - having the power to produce a desired result or effect; See

< http://www.merriam-webster.com/dictionary/efficacy> Retrieved online 23 January 2013. 
willing to bestow. Students failed, not institutions (Tinto, 2006, p.2). Hence, the verbal recognition of a first-year student, passed along by professionals within academia is an action a student rarely discounts. In his 2012 book, Tinto expressed, "student success is primarily a function of success in the classroom and the ability of the faculty to promote that success" (p. 87). If this professional, supportive relationship-building latches on and takes residence during the freshman to sophomore experience, said recognition given by the faculty to the student evolves into formal thoughts, personal goals and desired areas of academic focus. This observation is in line with the thinking asserted by Pajares, (1996), "Persuaders must cultivate people's beliefs in their capabilities while at the same time ensuring that the envisioned success is attainable" (paragraph 30). While one would surmise it is with the guidance and professional nurturing that often elicits this development, genuinely it appears that most students perceive there is adequate institutional support to make it through their chosen college path without incident or delay. Conversely, Upcraft, Gardner, \& Associates (1989; p. 8-9) suggested, "Because freshman rarely realize how institutional characteristics can affect their success, they often stack the deck against themselves when they choose an institution. Size, curricular, emphasis, control, location, selectivity, location [sic], and purpose all affect freshman success." Additionally, it bears noting that limits are undeniable with respect to what institutions can do to retain students (Tinto, 1987, p. 6). One could ascertain that sensibility dictated recognition of these limitations in the literature. On the other hand, authors DeWitz, Woolsey, and Walsh (2009; p. 19) reported, “The current study lends support to the idea of creating interventions based on self-efficacy theory in order to positively influence students' subjective sense of purpose in life for the purpose of improving college student retention." Therefore it is the selfefficacious student who stands a better chance at prevailing judiciously along their journey to 
and through higher education (Zimmerman, 2000, p. 17). In any event, expecting the first-year student to house the discernment necessary to formulate prudent patterns of creating alliances and navigating hardships is a myth many institutions would do well to dispel.

\section{Retention}

Retention as we know it now is measured and studied at a variety of junctures as students traverse through higher education. Some historical context offered by authors, Demetriou and Schmitz-Sciborski revealed, "Studies of undergraduate retention first appeared in the 1930s...The next great growth in higher education developed after World War II. The GI Bill had a dramatic influence on college student enrollment" (2011, p. 2). Subsequent review of literature led the focus primarily to the 1980s through 2012-2013. Studying retention rates in higher education has been viewed in the literature (Bean \& Eaton, 2001; Tinto, 1987; Tinto, 2012; Upcraft, Gardner \& Associates, 1989). Theorizing distinctions made a powerful debut. Emphasized by Bean and Eaton (2001; p. 74), "Modern retention studies began with Spady (1970) and are characterized by the use of sociological theory to link multiple variables in a longitudinal model." The number of students who begin their college career at a particular school as freshmen and proceed directly into their sophomore year, at the same school, the following year is assessed and the resulting percentage is then deemed the college's first-year retention rate. Consumers of higher education are given a choice. Bean and Eaton (2001; p. 73) pointed out that, "Participation in higher education is voluntary and is based on individual decisions to remain in or leave college." The higher the percentage calculated, the more pronounced the allure for the student to continue his or her college career at that institution. As the authors of 
scholarship aligned with the Inventory for Student Engagement and Success [ISES] $-2005^{3}$ conveyed:

Therefore, institutions might be tempted to focus on increasingly selectivity and recruiting 'the best and the brightest' students. But admitting only the best prepared students is tactic only a few institutions can afford to pursue. Moreover, it is not an approach that expands access or addresses the human capital needs of individuals or society (Kuh, Kinzie, Schuh, Whitt and Associates, 2005, p. 3).

Reaffirming the relationship between retention and student persistence, retention rates are often measured at a variety of levels and junctures in systems of higher education. For this reason, beginning investigation of literature and exposition thereof aligned with the linear progression of the first-year student experience in mind was crucial. Supposition of which is heavily supported. Tinto (2006; p. 3) charged, "We learned that involvement matters and that it matters most during the critical first year of college.” The time is now. Unprecedented efforts are required in designing and effectively administering supportive, learning environments aimed at boosting the capabilities of students to achieve their educational goals (Kun et al., 2005, p. 3). Review of the literature provided a robust amount of scholarship which denoted likeminded theory related to the need to formulate workable, measureable paths aimed at increasing retention rates. Upcraft, Gardner, \& Associates (1989; p. 7) declared, "If institutions are really serious about helping freshman succeed, they must take into account pre-enrollment variables, institutional characteristics, and institutional climate." Development and maintenance with regard to plans of action to proactively prevent student departure prove significant. Tinto (1987; p. 106) rendered, "The important point here is not merely that such distinct systems exist within the college.

\footnotetext{
${ }^{3}$ See Assessing Conditions to Enhance Educational Effectiveness: The Inventory for Student Engagement and Success,
} 
Rather it is that experiences in each may lead in a somewhat different fashion to varying modes of departure from the institution... One must also distinguish between the formal and informal manifestations of each system of the institution." Paying close attention to what is happening where, within institutions of higher education, and boldly taking action enhances the system of operations and is crucial to the success of students. Hence, with regard to augmenting rates affiliated with college retention, the literature offered likeminded scenarios and opinions with regard as to how best to do so. Or perhaps, to more succinctly subjugate that which is not working, it remains to be discovered which aspects of college success will most likely hold the attention and intention of the first-year college student.

Institutional Support redefined. Higher retention rates suggest that the first-year college student felt supported and had their needs met within the demographics of the institution. This reflection is in line with that which has already been predicted. Expect that each student requires assistance in defining college success. Expect that every student houses an attribute within themselves that will have a positive impact on the institution. Support the freshness of their upcoming first-year experience. Help them to recognize "the opportunity, the means, and the motivation" to navigate the process. Realize every step of the way, a first-year college student needs assistance in becoming acclimated to their new surroundings and in developing “a college self” (DeWitz et al., 2009, pp. 19-20). Whereby opportunities were in place to develop good working relationships with professors, and at the very minimum, the student was able to pass the courses they registered for. Points of which are shared and advocated by Bean (2005), "Professors affect the student's self-image and self-efficacy assessments. Faculty members deliver the institution's product, education. When students feel faculty members do not care 
about the student's development, their bonds to the institution weaken" (p. 225). The first year at an institution is a vital opportunity, which houses within it magnificent potential to connect with the students. This very formative first year is the precursor to the collective investment, both, the student and the institution make in one another.

For the student, if the relationship is workable and the positives of the first-year experience far outweigh the hurdles, the path ahead should be easily navigable. The academic trajectory before them, specifically the primary goal being the courses mapped out from the first term of the first year into the first term of their second year was obtainable. Conveyed by Bean (2005), "The commodity the student is purchasing from the school is this education, nebulous as the concept may be. An institution that does not provide courses that students want to take will have difficulty retaining its students" (p. 225). Additionally, the path ahead is ascertained as motivating and classes available to them are viewed as relevant.

From the first class experience throughout the first year, the student envisioned manageable steps, with respect to being successful at their role as a college student and planned to stay in college. Individual decisions weigh heavily on the results formed collectively, better known as retention rates (Bean and Eaton, 2001, p. 73). One step at a time, increased selfefficacy and trust in the support of the institution should prove attainable. Resources should be in place to assist the student in being successful. These resources—aligned with peer support, institutional support services, combined with support of faculty and staff-equate with that which is connected to their future at an institution of higher learning (Wilson and Gore, 2013, 178). Additionally, Wilson and Gore described, "connectedness to the university is defined as students' subjective sense of overall fit within the university and the perception that they are personally accepted, respected, included, and supported by others at the university" (2013, p. 
178). Such connectedness could likely provide positive outcomes with regard to efficacy of systems, combined with students' increased self-efficacy, which solidly stand the tests of time and harsh economic factors. Thus, creating and nurturing professional relationship-building, while developing systems aligned with connectedness worthy of institutional support.

Equally important, these new-to-the-institution and potential (four-year) consumers of education at that same institution viewed the cost of attendance affordable. As established by author John P. Bean (2005; p. 235), lower tuition for the student relates to higher retention rates for the institution. Consequently, should this relationship-building between student and institution not be maintained at a measureable and supportive rate, the impact can be detrimental to the wherewithal available to a student. Every effort should be made to maintain affordability and access. Bean and Eaton (2001; p. 73) argued, "Institutional policies and practices do affect rates of student retention and institutions are far from helpless when it comes to creating programs and environments that attract or repel students." Hence, the management of systems affiliated with higher education nationwide remained equally impacted by their decision-making processes. Well-known student retention scholar Vincent Tinto (2012; p. 107) emphasized, "Since individuals nearly always support what they create, an organizing committee, office, or team should see its work as facilitating the actions of other offices and persons. Its ability to take or initiate action should generally result from the way it provides targeted incentives or resources that promote the actions of others." Noted tangibly throughout the literature-discussions likened to this clearly consume much meeting and discussion time in the realm of academia.

Perceived Self-efficacy. Bandura (1982; p. 122) charged, "Perceived self-efficacy is concerned with judgments of how well one can execute courses of actions required to deal with 
prospective situations." Beliefs people house within pertaining to their ability to perform and produce distinctive results signifies their perceived self- efficacy. These beliefs regulate "how people feel, think, motivate themselves and behave" (Bandura, 1994, p. 117). The concept of self-efficacy was drawn from Social Cognitive Theory, spawned from a base of knowledge relative to interpreting perceived abilities as realized and justified on an individual basis. Any ensuing personally efficacious development is assimilated with stemming from (and is determined) within. Connections between the particular capabilities of college students and the results he or she produces often fall short of the expectations of others. In the same way, "Selfefficacy theory acknowledges the diversity of human capabilities” (Bandura, 1997, p. 36). Distinctly, the subject of perceived self-efficacy has been an ongoing focal point within populations encompassing the realm of higher education and successful completion thereof. As concluded by Bean (2005; p.237), “Assessment usually is most effective when the causes and effects of programs are clearly understood and easily measured. Such is rarely the case in retention." For this reason, when seeking to develop and measure processes of college success and student persistence, including a variety of elements related directly to perceived selfefficacy, institutional support and retention rates would likely serve as useful information. Especially when redefining institutional support. Accordingly, future research should focus on defining, measuring, and assessing relational aspects of these constructs.

Based on the review of literature, the relationship between academic self-efficacy and student retention has been established (Bandura, 1994; Chemers, Hu, \& Garcia, 2001; Gore, 2006; Pajares, 1996, 2002, 2006). However, the relationship between perceived self-efficacy and support of college institutions and retention is less well understood. Therefore, as established previously in this text, the information gathering accomplished during this honors thesis remains 
slated for future use aligned with the development of adult-learning workshops and educational tools. Further envisioned are processes intent on examining and ultimately defining (and redefining) factors affiliated with the less well understood relational constructs of college retention and institutional support during the first-year college experience, among others. A review of the literature and perspective thereof concluded, both, institutional support and being retained successfully can improve the effectual behavior of students. Further affirmation of which was noted in the literature, “Clearly, students' self-efficacy beliefs are responsive to changes in instructional experience and play a causal role in students' development and use of academic competencies" (Zimmerman, 2000, p. 8). Thus, distinct patterns remained with respect to academic improvement. In the final analysis,

Though institutions can and should learn from the experiences of other colleges and universities, it is for each institution to discern for itself the particular events which shape student departure from its campus...effective assessment must be sensitive to the broad range of student experiences and the longitudinal character of student passage through the institution. More importantly, it must enable the institution to capture the quality of those experiences as they are understood by the student. Assessment must, in this sense, be grounded in the common experience of students as they pass through the institution (Tinto, 1987, p. 7).

In sum, the responsibility to provide and maintain workable paths to college success for the consumers of higher-education remains a shared one.

Personal reflections. Portland State University is my home for higher education. Accordingly, this submission is just the first segment in an adult-learning series. Hence, my 
baccalaureate thesis was aligned with investigating instruments of assessment and previously collected data from Portland State University students. Reflective parametric assessment of this data provided a hearty discussion to my thesis question: How does institutional support lead to first-year college student retention? In turn, this review of literature and produced text purposefully laid the groundwork for my future journey into the development of a survey instrument, envisioned to effectively build upon the body of work relative to retention rate measurement and analysis.

Through this review of past and present scholarship relatable to retention and perceived self-efficacy, and a deeper assessment of each, conclusions were hypothesized. Invaluable knowledge was gained that significantly showed the importance of one to the other. Aligning institutional support with these conclusions provided tangible patterns of interest for future research.

During the thesis development and assessment of previously collected data, sessions of gaining insight from professionals directly involved in the data collection and assessment processes were integral. As well as the frequent dialogue with those who make their livings making decisions directly related to first-year college students and the retention schematics at this institution of higher education, all pedagogically inspiring.

Frankly, the journey leading to this point of completion has been challenging on many levels. Prospectus to presentation, many times throughout production of this honors thesis uncertainty infiltrated; however, and most importantly, there was never a doubt that the journey would successfully be completed. Living my dream; as for me, setting these (at times) lofty, educational goals and accomplishing them are dreams come true. Hence the inspiration for the 
title of this inaugural project and starting point for future evidence-based contributions under the duly noted and inspiring umbrella, DETERMINED: Start to Finish.

With the patient guidance of the team (Leslie B. Hammer, Ph.D., Rachel Webb, M.S. Statistics and Scott Broussard, M.S.) of professionals that signed on with me, I met this honors requirement, acquired an enormous amount of knowledge, and purposefully accomplished my intent (and one of the main reasons for having moved my life to Portland) in successfully completing this thesis. Each member of this team is a shining example of what institutional support can and should look like. The individual and collective support they have afforded me before and during this thesis process was paramount to my success as a Portland State University student.

Inspired more than ever to continue the path envisioned, to further tap into that which is determined within. Intent on producing instruments of analyses which will likely be useful in further arenas of assessment and development of scales with respect to self-efficacy as it correlates with college retention and institutional support. Specifically, this author stands firm in agreement with scholars who accept their respective parts of this learning tree of accountability. We as a nation should be encouraging students to develop that which is determined within and providing them the tools, options, and support to proceed through their college years with fervent adoration for the journey to and through higher education. Especially those professionals affiliated with the development of programs intended to inspire and acquire higher numbers of students retained. Boldly stated, "If retention programs are to work they must work for each student involved in the program" (Bean \& Eaton, 2001, p. 73). There is a delicate balance between nurturing the perceived ability a student has toward their success of becoming a college graduate and the very real goal that signify retention rates as a measure of future funding for the 
institution of higher-learning. Thinking critically and respecting individuality should go hand-inhand; but, do scholars of education- and government-based research agree? Tinto (2102; p.25) illustrated, "Nothing is more important to student retention than academic support, especially during the critical first year of college." Clearly, this statement is noteworthy. As institutional support relative to credence aligned with this statement would likely enhance retention rates of any institution. Additionally, said support would likely enhance purposeful academic engagement and persistence of the institution's students long term.

During this honors thesis development, recent national and local data was examined. In turn, visuals (noted on page 6-7 and shared within this text - Appendix A and Appendix B) were developed related to relationships between just a few demographics and variables pertaining to how retention has been measured and assessed in recent years at Portland State University. Subsequently, any information viewed remains slated for use in further exploration and development of a survey and/or data collection instrument for use into this upcoming graduate program; intent on examining scholarship in the areas of education and government policy with respect to retention and graduation rates within the realm of academia.

\section{Conclusion}

The consumer of higher education perceives the institutional support offered prior to beginning their first term will be what he or she is afforded during their first year. Thus, the perceived self-efficacy of the student increases when supported in the freshman to sophomore experience, as is common when support is received in any new undertaking of this magnitude. Once the student begins their journey through higher education, and if the perceived institutional support is more and the actual institutional support received is less than anticipated, trust in the institution and the desire to remain at the college for future terms is impacted. 
Hence, retention decreases and attrition increases; subsequently, the student and the institution, respectively, are disengaged. For this relationship to dissolve equates to an unfortunate loss of furtherance, retention, and revenue potential. The student equates (both) the challenges faced and their inability to navigate them with personal failure. In reality, the misstep could have potentially been avoided had institutional support remained distinctly aligned. The connected elements of continual support are shared within the Gallup-Purdue Index Report 2014, ${ }^{4}$ Great Jobs, Great Lives, p. 15), "More college graduates who felt supported in collegebecause they had a mentor who encouraged them to pursue their goals and dreams, a professor who made them excited about learning, and felt their professors cared about them as a personare thriving in all areas of their well-being." Therefore, it stands to reason when a student is provided with even a slight amount of illumination on the often dark and narrow pathways which lead to success it can fuel that which is determined within. Enhanced levels of efficacy serve as useful throughout, especially for the new-to-the-institution student. Whereby, special consideration of challenges facing students are worthy of purposeful discussion for forward growth to transpire. Bandura (2011; p. 32) explained, "There is a marked difference between possessing knowledge and skills and being able to use them well under diverse circumstances, many of which contain ambiguous, unpredictable and stressful elements. Self-efficacy plays an influential role at the operative level." It takes less time to realign measures of support and strengthen a first year student's efficacy, than to rework their plan altogether. In its infancy of development, one's perceived self-efficacy is fragile. It is more difficult to rebuild efficacy once it has experienced negative affect. (Bandura, 1994; Pajares, 1996). Therefore, producing concrete

\footnotetext{
${ }^{4}$ See page $15<$ http://www.gallup.com/poll/168848/life-college-matters-life-college.aspx $>$; Link to request full report $\rightarrow$ <http://products.gallup.com/168857/gallup-purdue-index-inaugural-national-report.aspx >
} 
pathways to college success and being open to redefinition of institutional support directly aimed at providing discernable and accessible resources for the student equate to, for the institution, a consumer who is vested. 


\section{Areas of Interest \& Future Research}

Figure 1.

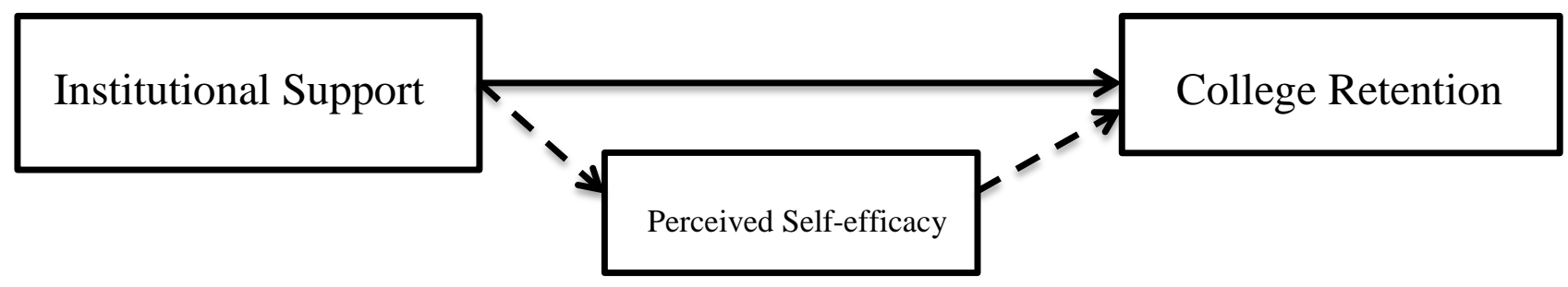

Freshman $\rightarrow$ Sophomore Experience

Future Research will include this thesis-related question and alternate operational definitions of institutional support for use survey development and data acquisition:

- What role does institutional support play in college retention?

Hypothesis 1: The more institutional support a student receives, the more likely they are to be retained.

Hypothesis 2: The more institutional support a student receives, the more likely they are to have a heightened efficacy of self. 


\section{Future Research (continued) - for use in this series}

1. Future research aligned with this text, future series additions, and development of survey instruments related to college retention and the impact of institutional support received by the students will boldly address and include items similar, but not limited to:

1.1. Does functional, clearly defined wording used in survey development enhance the likelihood of higher response rates and acquiring data which signifies true concerns of the student, applicable to retention?

1.1.1. Does the student know what is expected of them as a student?

1.1.2. Does the student know how to formulate and ask questions that will aid in their success as a student?

1.1.3. Does the student feel welcomed and included at the institution?

1.1.4. Does the student treat others in a welcoming and inclusive manner?

1.1.5. Does the student know how to ask for institutional support?

1.1.6. Does the student know institutional support means more than monetary support?

1.1.7. What notable variances exist [if any] relative to institutional support received by in-state students versus out-of-state students?

1.1.8. What notable variances exist [if any] relative to institutional support received based on gender?

1.1.9. What notable variances exist [if any] relative to institutional support received based on ethnicity?

1.1.10. What notable variances exist [if any] relative to class-standing [freshmen, sophomore, junior, and senior] in college?

1.2. Does it cost Portland State University more to retain or recruit students?

1.2.1. Compared to other institutions of higher education in our nation?

1.2.2. Compared to other institutions of higher education in other nations?

2. Does receiving institutional support lead to being of service to your peers and community?

Hypothesis 1: The more institutional support a student receives in college, the more likely their commitment to mentor other students.

Hypothesis 2: The more institutional support a student receives in college, the more likely their commitment to volunteer in the local community, outside of the college or university.

3. In a continued effort to focus on the positive, while building on past scholarship - What adjustments need to be made and/or perspectives need to be illuminated to develop surveys and/or other measures of assessment to most effectively gather the most useful information from the students?

3.1. Does investing in students during the undergraduate program produce a more serviceminded graduate and community member?

3.2. Does the relational impact of receiving institutional support as an undergraduate constitute philanthropic outcomes once graduated?

3.2.1. If so, are these benevolent acts largely monetary in nature, resources, gifts of time, or combinations thereof? 


\section{Future Research (continued) - for use in this series}

Hypothesis 1: The more institutional support a student receives while in college, the more likely that student is to support the institution after graduation.

Hypothesis 2: The more institutional support a student receives in college, the more likely the student is to feel connected to the institution as an alumnus, the more efficacy of self is increased; potentially leading to the outcome of contributions to the institution and encouraging others to attend the college in the future.

Figure 2:

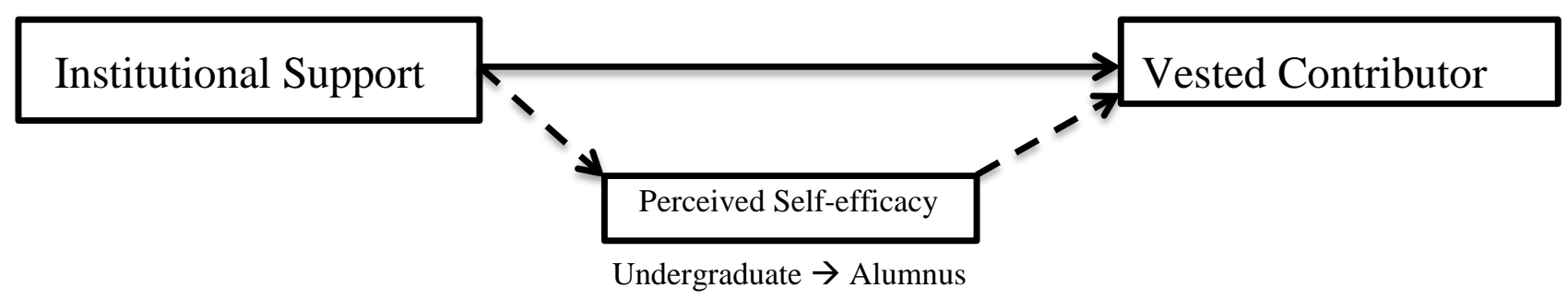




\section{APPENDIX A}

\section{FRESHMAN INQUIRY ASSESSMENT}

\section{TOOLS AND METHODS}

\section{Prior Learning Survey}

Purpose: The Prior Learning Survey asked about students' academic experiences prior to attending PSU, reasons for and concerns about attending college, and early college experiences and plans. The survey results provide information to individual faculty about their students and to the program about the overall preparation and needs of the incoming freshman class.

Method: During the first two weeks of Fall 2012, Freshman Inquiry students completed a Prior Learning Assessment. This on-line survey was administered during FRINQ mentor sessions. 1,089 students completed the survey for a $91 \%$ response rate.

\section{FRINQ End-of-year Survey}

Purpose: The FRINQ End-of-year Survey asked students to rate their experiences in their FRINQ course over the 2012-2013 academic year. Students responded to questions about the course format, faculty pedagogical practices, and mentor contribution to the course. The survey also asked about experiences with advising, comfort on campus and plans for the fall term. The results provide information to individual faculty about their course and to the program about students' overall experience in FRINQ.

Method: During the final three weeks of Spring term 2012, FRINQ students completed the End-of-year survey. This on-line survey was administered during mentor sessions. 787 students responded to the survey for a response rate of $77 \%$. 


\section{APPENDIX B}

Graphs developed for and discussed briefly in this honors thesis are reflective of most recent data obtained from Portland State University students. Comparing relationship between retention and ethnicity, gender, and residency status, respectively.

\section{Freshman to Sophomore - Retention by Ethnicity}

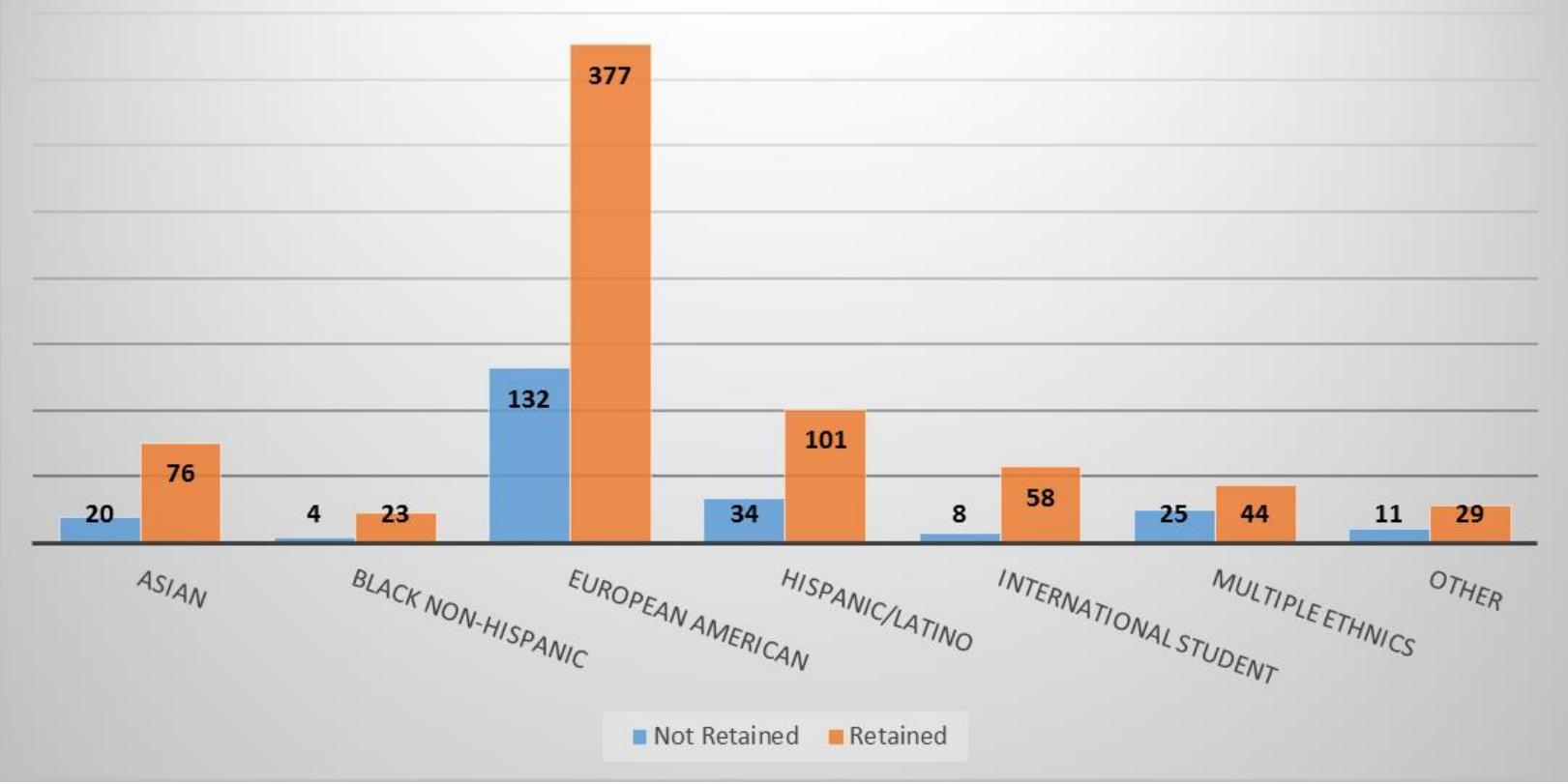

Chi-squared test for first-year retention relative to ethnicity:

\begin{tabular}{|l|r|l|l|l|l|l|r|r|}
\hline & Asian & $\begin{array}{l}\text { Black Non- } \\
\text { Hispanic }\end{array}$ & $\begin{array}{l}\text { European } \\
\text { American }\end{array}$ & $\begin{array}{l}\text { Hispanic/ } \\
\text { Latino }\end{array}$ & $\begin{array}{l}\text { International } \\
\text { Student }\end{array}$ & $\begin{array}{l}\text { Multiple } \\
\text { Ethnics }\end{array}$ & Other & Total \\
\hline $\begin{array}{l}\text { Not } \\
\text { Retained }\end{array}$ & 20 & 4 & 132 & 34 & 8 & 25 & 11 & 234 \\
\hline Retained & 76 & 23 & 377 & 101 & 58 & 44 & 29 & 708 \\
\hline Total & 96 & 27 & 509 & 135 & 66 & 69 & 40 & 942 \\
\hline
\end{tabular}

\begin{tabular}{|l|r|r|r|r|l|l|r|r|}
\hline & \multicolumn{1}{|l|}{ Asian } & $\begin{array}{l}\text { Black Non- } \\
\text { Hispanic }\end{array}$ & $\begin{array}{l}\text { European } \\
\text { American }\end{array}$ & $\begin{array}{l}\text { Hispanic/ } \\
\text { Latino }\end{array}$ & $\begin{array}{l}\text { International } \\
\text { Student }\end{array}$ & $\begin{array}{l}\text { Multiple } \\
\text { Ethnics }\end{array}$ & Other & Total \\
\hline $\begin{array}{l}\text { Not } \\
\text { Retained }\end{array}$ & 23.85 & 6.71 & 126.44 & 33.54 & 16.39 & 17.14 & 9.94 & 234 \\
\hline Retained & 72.15 & 20.29 & 382.56 & 101.46 & 49.61 & 51.86 & 30.06 & 708 \\
\hline Total & 96 & 27 & 509 & 135 & 66 & 69 & 40 & 942 \\
\hline
\end{tabular}

$p$-value $=0.0388$ 
APPENDIX B (continued)

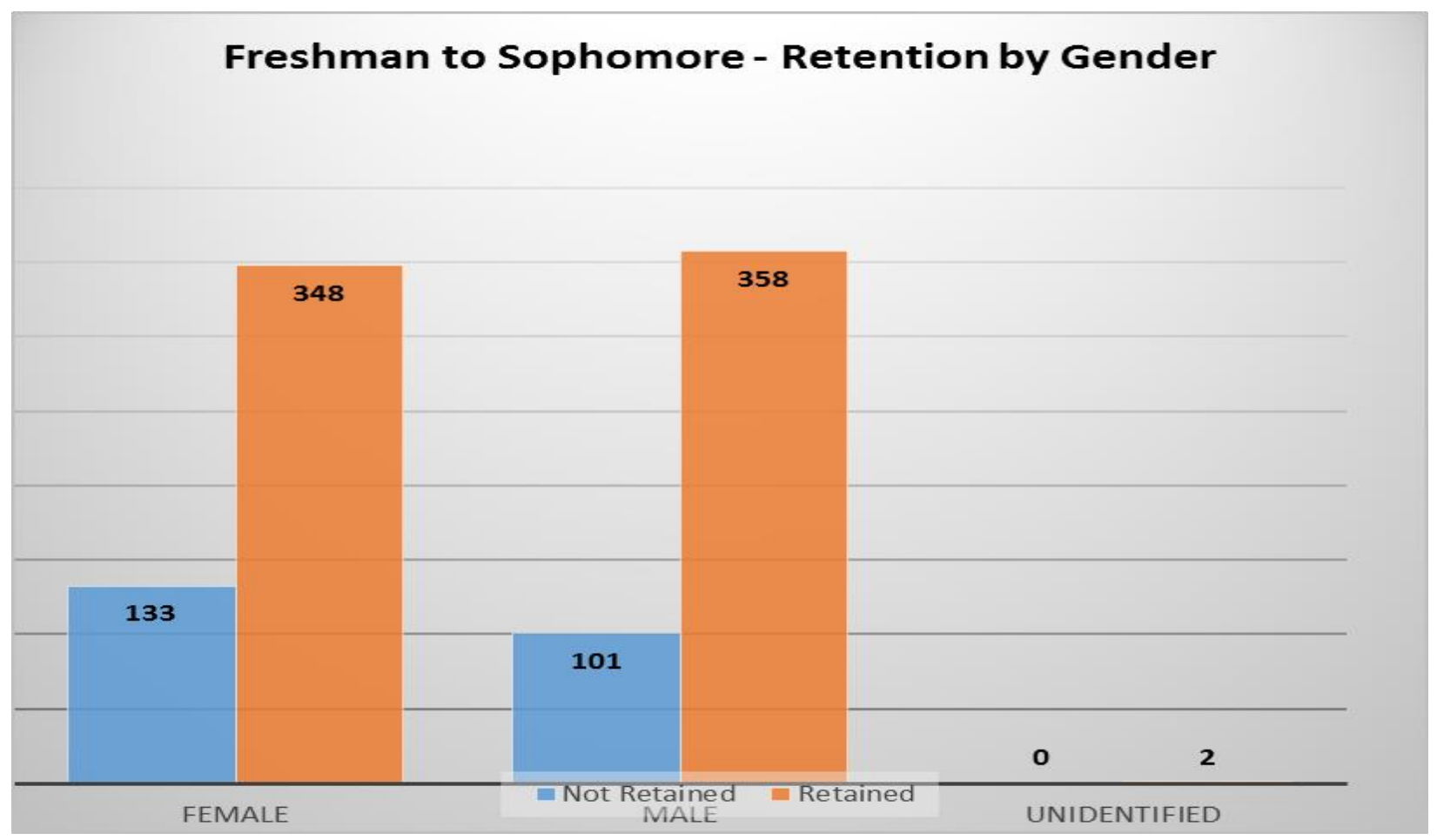

Tabulated Statistics: Retention and Gender

Rows: Retention Columns: Gender

\begin{tabular}{|c|c|c|c|c|}
\hline & $\mathrm{F}$ & $\mathrm{M}$ & $\mathrm{U}$ & All \\
\hline 0 & $\begin{array}{r}133 \\
56.84 \\
27.65\end{array}$ & $\begin{array}{r}101 \\
43.16 \\
22.00\end{array}$ & $\begin{array}{r}0 \\
0.00 \\
0.00\end{array}$ & $\begin{array}{r}234 \\
100.00 \\
24.84\end{array}$ \\
\hline 1 & $\begin{array}{r}348 \\
49.15 \\
72.35\end{array}$ & $\begin{array}{r}358 \\
50.56 \\
78.00\end{array}$ & $\begin{array}{r}2 \\
0.28 \\
100.00\end{array}$ & $\begin{array}{r}708 \\
100.00 \\
75.16\end{array}$ \\
\hline All & $\begin{array}{r}481 \\
51.06 \\
100.00\end{array}$ & $\begin{array}{r}459 \\
48.73 \\
100.00\end{array}$ & $\begin{array}{r}2 \\
0.21 \\
100.00\end{array}$ & $\begin{array}{r}942 \\
100.00 \\
100.00\end{array}$ \\
\hline \multicolumn{2}{|c|}{ Cell Contents: } & \multicolumn{3}{|c|}{$\begin{array}{l}\text { Count } \\
\frac{\circ}{\circ} \text { of Row } \\
\% \text { of Column }\end{array}$} \\
\hline \multicolumn{5}{|c|}{$\begin{array}{l}\text { Pearson Chi-Square }=4.673, \mathrm{DF}=2 \\
\text { Likelihood Ratio Chi-Square }=5.160, \mathrm{DF}=2 \\
\text { * WARNING * } 1 \text { cells with expected counts less than } 1 \\
\text { * WARNING * Chi-Square approximation probably invalid }\end{array}$} \\
\hline
\end{tabular}


APPENDIX B (continued)

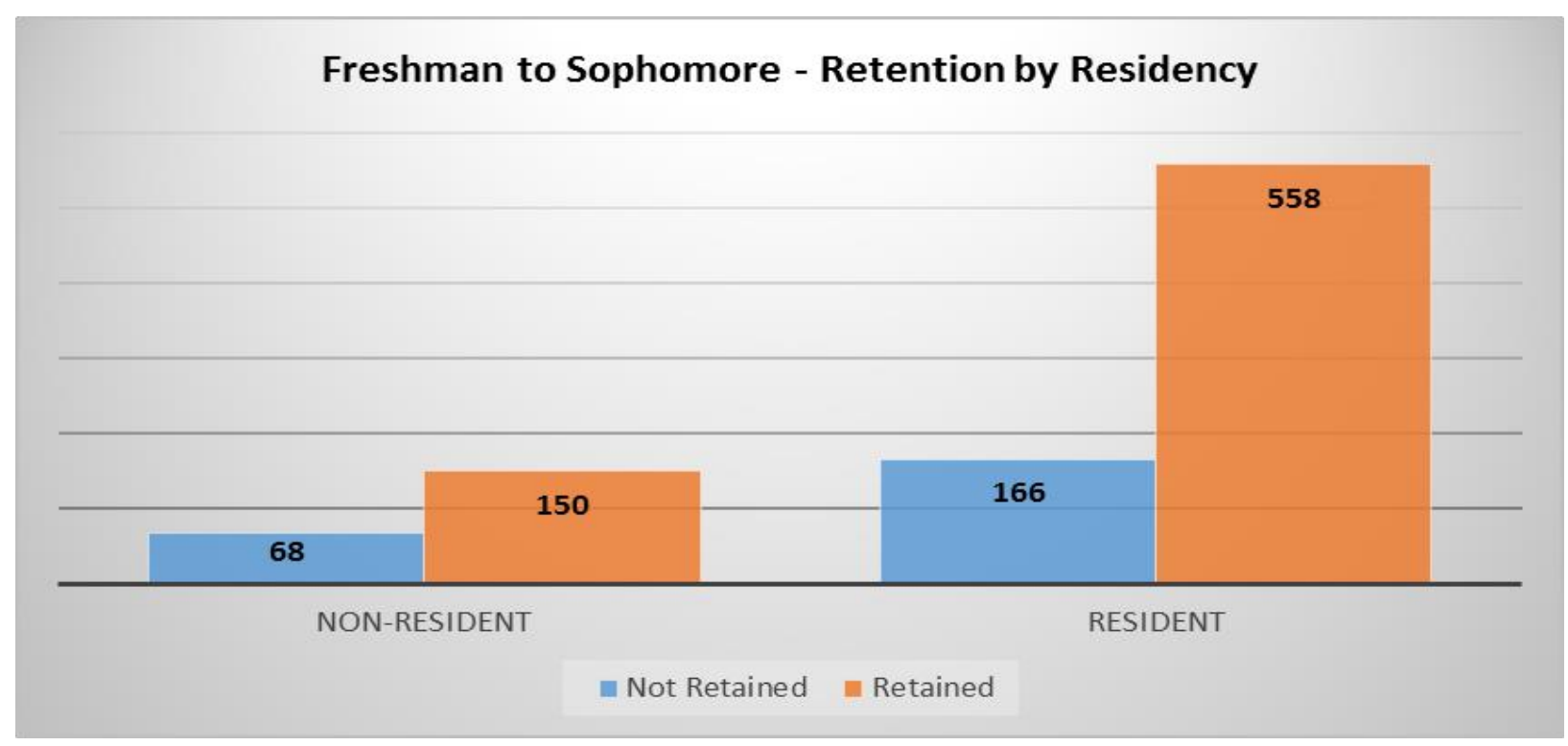

Tabulated Statistics: Retention and Residency

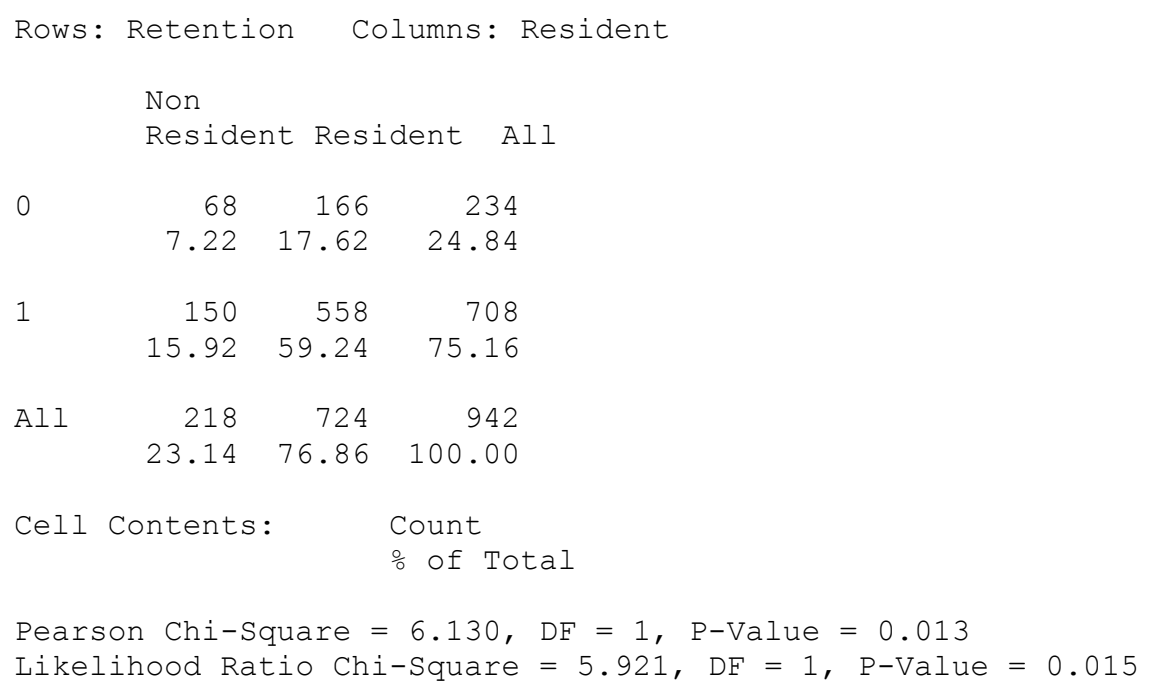




\section{References}

Bandura, A. (1982). Self-efficacy mechanism in human agency. American Psychologist, 37(2), 122-147.

Bandura, A. (1994). Self-efficacy. In V. S. Ramachaudran (Ed.), Encyclopedia of human behavior (Vol. 4, pp. 71-81). New York: Academic Press. (Reprinted in H. Friedman [Ed.], Encyclopedia of mental health. San Diego: Academic Press, 1998).

Bandura, A. (1997). Self-efficacy: The exercise of control. New York: W. H. Freeman \& Co.

Bandura, A. (2011). On the functional properties of perceived self-efficacy revisited. Journal of Management. 38(1), 9-44. doi: 10.1177/0149206311410606

Bean, J. P. (2005). Nine themes of college student retention. In Seidman (Ed.), College Student Retention: Formula for college success (pp. 214-43). Westport, CT: Praeger Publishers.

Bean, J.P. \& Eaton, S. (2001). The psychology underlying successful retention practices. Journal of College Student Retention: Research, theory \& practice, 3(1), 73-89. doi: 10.2190/6R55-4B30-28XG-L8U0

Demetriou, C. \& Schmitz-Sciborski, A. (2011). Integration, motivation, strengths and optimism: Retention theories past, present and future. In R. Hayes (Ed.), Proceedings of the 7th National Symposium on Student Retention, 2011, Charleston. (pp. 300-312).

DeWitz, S. J., Woolsey, M. L., \& Walsh, W. B. (2009). College student retention: An exploration of the relationship. Journal of College Student Development, 50(1), 19-34. doi: 10.1353/csd.0.0049

Kuh, G. D., Kinzie, J., Schuh, J. H., Whitt, E. J. (2005). Assessing conditions to enhance educational effectiveness: The inventory for student engagement and success. (1 ed., Vol. 1, p. 12). Jossey-Bass.

Pajares, F. (1996). Self-efficacy beliefs in academic settings. Review of Educational Research. 66(4), 543-578.

Pajares (2002). Overview of social cognitive theory and of self-efficacy. Retrieved May 23, 2013 from http://www.emory.edu/EDUCATION/mfp/eff.html

Tinto, V. (1987). Leaving college: Rethinking the causes and cures of student attrition. Chicago, IL.: The University of Chicago Press. 
Tinto, V. (2006). Research and practice of student retention: What next? Journal of college student retention , 8(1), 1-19.

Tinto, V. (2012). Completing college: Rethinking institutional action. Chicago, IL: The University of Chicago Press.

Upcraft, M. L., Gardner, J. N., \& Associates. (1989). The freshman year experience: Helping students survive and succeed in college. San Francisco, California: Jossey- Bass, Inc.

Wilson, S., \& Gore, J. (2013). An attachment model of university connectedness. The Journal of Experimental Education, 81(2), 178-198. doi: 10.1080/00220973.2012.699902

Zimmerman, B. J. (2000). Self-efficacy: An essential motive to learn. Contemporary Educational Psychology. 25, 82-91. Doi: 10.1006/ceps/1999.1016 